\title{
MAKNA BUDAYA PADA ELEMEN ARSITEKTUR RUMAH GADANG BODI CANIAGO MINANGKABAU DI PROPINSI SUMATRA BARAT
}

\author{
Aulia Abrar \\ Jurusan Teknik Arsitektur, Akademi Teknik YKPN Yogyakarta, \\ Jl. Gagak Rimang No. 1, Balapan, Yogyakarta \\ e-mail: mmmindoauliaabrar81@gmail.com
}

\begin{abstract}
Abstrak
Arsitektur Tradisional Minangkabau mempunyai kekhasan dan ciri tersendiri baik dalam bentuk arsitektural maupun filosofinya. Bentuk bangunannya mempunyai hubungan yang erat dengan setting sosial budaya masyarakat. Karakteristik suatu bangunan dapat ditinjau melalui metode kualitatif rasionalistik berdasarkan teori topologi, morfologi dan tipologi. Elemen-elemen arsitektur tradisional dapat menjadi karakteristik dari suatu daerah tersebut. Sehingga, setiap hasil karya yang diciptakan tersebut benar-benar mempunyai landasan yang kuat dan khas, baik dari segi struktur, bentuk fasad, tata ruang dan juga pemakaian ornamen-ornamennya. Bentuk yang khas dan spesifik tersebut mampu menampilkan bentuk yang selaras dengan lingkungannya sehingga mampu mengingatkan orang atau masyarakat terhadap suatu lingkungan tersebut. Bentuk yang demikian menjadikan bentuk arsitektur Minangkabau menjadi mudah diingat dan dikenal dimana saja karena apa pun yang dibuat mempunyai landasan yang kuat dan benar-benar khas.
\end{abstract}

Kata Kunci: Minangkabau, elemen arsitektur tradisional, karakteristik, struktur, bentuk fasad, tata ruang, ornamen, selaras.

\begin{abstract}
Title: The Meaning of CaniagoStyle of Minangkabau Architecture in West Sumatra Province

Minangkabau Traditional Architecture has its own characteristics, both in architectural and philosophical. The shape of the building has a close relationship with the socio-cultural setting of the community. The characteristics of a building can be reviewed through rationalistic qualitative methods based on topology, morphology and typology theories. Traditional architectural elements can be characteristic of an area. So, each of the works created really have a strong and unique foundation, both in terms of structure, facade shape, spatial layout and also the use of its ornaments. The specific form is able to display forms that are in harmony with their environment so that they are able to remind people or the community of that environment. This form makes the Minangkabau architecture easy to remember and known everywhere because whatever is created has a strong foundation and is truly specific.
\end{abstract}

Keywords: Minangkabau, traditional architecture elements, characteristics, structure, facade, spatial, ornament, harmony. 


\section{Pendahuluan}

Pengertian makna budaya adalah suatu cara hidup yang berkembang, dimiliki bersama oleh sebuah kelompok orang dan diwariskan dari generasi ke generasi. Budaya terbentuk dari banyak unsur yang rumit, termasuk sistem agama dan politik, adat istiadat, bahasa, perkakas, pakaian, bangunan dan karya seni. Dalam hal ini makna budaya adalah sistem bangunan dalam Arsitektur Minangkabau.

Di wilayah Minangkabau dikenal dengan Luhak Nan Tigo, yaitu: Luhak Tanah Datar, Luhak Agam dan Luhak 50 Kota. Ketiga Luhak ini sering disebut dengan darek. Wilayah Minangkabau yang sebenarnya adalah bukan sebagaimana kita lihat daerah Sumatera Barat sekarang ini, tetapi lebih kecil besaran wilayahnya.

Masyarakat Minangkabau hidup dalam suatu tatanan sosial berupa keluarga besar (paruik) yang berasal dari satu keturunan ninik, dimana setiap satu keturunan keluarga dipimpin oleh seorang mamak. Setiap keluarga mempunyai rumah Gadang masingmasing, dimana di dalamnya berlangsung aktivitas keluarga yang didominasi oleh pihak perempuan. Yang menempati rumah Gadang tersebut adalah perempuan dan anakanak, sedangkan yang laki- laki tinggal di surau untuk belajar mengaji dan menuntut ilmu.

Membicarakan masalah arsitektur Minangkabau, tidak bisa dilepaskan dari kedua hal di atas, yaitu geografisnya dan juga sosial budayanya. Arsitektur Minangkabau mempunyai kaitan yang erat dengan hal tersebut, rumah Gadang sebagai tempat tinggal suatu keluarga besar merupakan karya nyata masyarakat Minangkabau yang terdapat pada ketiga Luhak tersebut. Aktivitas yang dilakukan di dalamnya merupakan pola dan tata budaya yang dianut dalam berkehidupan sosial. Orang Minang hidup berfalsafahkan alam takambang jadi guru (alam terbentang jadi guru), yang mana di dalamnya banyak hikmah yang bisa diserap sebagai contoh berperilaku dalam hidup dan berbudaya sehari-hari.

Menurut Usman (1995), ada tiga hal perwujudan hasil budaya Minangkabau yang dapat dirasakan oleh pengamat, yaitu:

1. Ideal (mengandung nilai-nilai atau norma)

2. Tingkah laku berpola (upacara seremonial)

3. Fisik (karya nyata)

Yang dimaksud dengan arsitektur Minangkabau tersebut ialah karya nyata masyarakat Minangkabau ke dalam wujud fisik, dimana wujud dan bentuknya merupakan pengejawantahan sistem dan tatanan sosial budaya yang berlaku dalam kehidupan sehari-hari masyarakat Minangkabau ketiga Luhak tersebut.

Masyarakat awam sering mengenal arsitektur rumah bagonjong (bergonjong), dimana atapnya melengkung dan badannya melendut di bagian tengah. Bentuk ini banyak dipakai sebagai wujud arsitektur Minangkabau, namun sebenarnya masih mempunyai banyak ragam hias berdasarkan tipe-tipenya. Sebagaimana telah kita ketahui bahwa masyarakat Minangkabau hidup berkelompok berdasarkan keluaga besarnya (paruik) atau sering disebut suku, ada suku Bodi Caniago, Koto Piliang dan lainlain. Setiap suku mempunyai rumah Gadang masing-masing dan bentuk yang ditampilkannya mempunyai ciri khas tertentu. Perbedaan ini 
diakibatkan perbedaan pola dan tatanan budaya yang dianut setiap suku berdasarkan keselarasan yang dianut.

Dalam tradisi masyarakat Minangkabau, tambo merupakan suatu warisan turun-temurun yang disampaikan secara lisan. Daerahdaerah yang termasuk Lareh Bodi Caniago disebut juga dalam tambo "Tanjuang Nan Tigo, Lubuak Nan Tigo".

\section{Tanjuang Nan Tigo \\ - Tanjuang Alam \\ - Tanjuang Sungayang \\ - Tanjuang Barulak}

2. Lubuak Nan Tigo

- Lubuak Sikarah di Solok

- Lubuak Simauang Sawahlunto Sijunjung

- Lubuak Sipunai di Tanjuang Ampalu

Selain Lubuak Nan Tigo dan Tanjuang Nan Tigo, yang termasuk Lareh Bodi Caniago juga adalah Limo Kaum XII Koto dan sembilan anak kotonya. Daerah yang termasuk XII Koto adalah: Tabek, Sawah Tengah, Labuah, Parambahan, Sumpanjang, Cubadak, Rambatan, Padang Magek, Ngungun, Panti, Pabalutan, Sawah Jauah. Sembilan anak koto terdiri dari: Tabek Boto, Salaganda, Baringin, Koto Baranjak, Lantai Batu, Bukik Gombak, Sungai Ameh, Ambacang Baririk, Rajo Dani. Sedangkan pusat pemerintahan terletak di Dusun Tuo Limo Kaum.

Dalam mengambil suatu keputusan adat Bodi Caniago berpedoman kepada:

"kato surang dibuleti katobasamo kato mufakat, lah dapek rundiang nan saiyo, lah dapek kato nan sabuah, pipiah dan indak basuduik bulek nan indak basandiang, takuruang makanan kunci, tapauik makanan lantak, saukua mako manjadi, sasuai mangko takana, putuih gayuang dek balabeh, putih kato dek mufakat, tabasuik dari bumi..."

Artinya, kata seorang dibulati, kata bersama kata mufakat, sudah dapat kata yang sebuah, pipih tidak bersudut, bulat tidak bersanding, terkurung makanan kunci, terpaut makanan lantak, seukur maka terjadi, sesuai maka dipasangkan, putus gayung karena belebas, putus kata karena mufakat, tumbuh dari bumi. Sehingga maksud dari sistem adat Bodi Caniago ini yang paling diutamakan adalah sistem musyawarah mencari mufakat.

\section{Permasalahan dan Tujuan}

di

Permasalahan yang terkait makna budaya pada elemen aristektur rumah Gadang Bodi Caniago di Sumatera Barat adalah minimnya pengungkapan pengetahuan makna budaya pada elemen rumah Gadang Bodi chaniago. Sedangkan tujuan dari makna budaya pada elemen aristektur rumah Gadang Bodi Caniago di Sumatera Barat adalah untuk mengungkapkan gambaran makna budaya dari elemen aristektur rumah Gadang Bodi Caniago di Sumatera Barat untuk menginpirasi pengembangan budaya masyarakat Minangkabau.

\section{Kajian Pustaka}

Untuk memahami makna dan nilai suatu tempat (place), menurut Schulz dalam Agus (1999) ada tiga kelompok aspek yang perlu ditinjau, yaitu:

\section{Topologi}

Topologi menyangkut tatanan spasial (spatial order) dan pengorganisasian ruang (spatial organization), dimana ruang (space) berkaitan dengan tempat (place) daripada ruang abstrak yang matematis. Hal ini berarti lebih merujuk pada orientasi kegiatan 
manusia pada suatu tempat tertentu, berkaitan dengan karakteristik suatu tempat (place) dalam hal penggunaan suatu lingkungan binaan tertentu, bukan hanya sekedar mewadahi kegiatan fungsional secara statis, melainkan menyerap dan menghasilkan makna berbagai kekhasan suatu tempat seperti:

1. Setting bangunan fisik

2. Komposisi dan figurasi bangunan dengan ruang publik

3. Kehidupan masyarakat setempat

Perwujudan spasial fisik merupakan produk kolektif dari perilaku budaya masyarakatnya serta pengaruh "kekuasaan" tertentu yang melatar belakanginya. Secara visual elemen lingkungan sebenarnya merupakan keterpaduan atas semangat tempat (the spirit of place) yang berorientasi pada lingkungan lokal.

Identitas tidak bisa diciptakan secara seketika (instant). Pencapaiannya melalui hierarki tertentu yang teratur dan berulang. Identitas kampung tradisional merupakan jejak peradaban yang ditampilkan sepanjang sejarah kampung tradisional itu sendiri, hal ini selaras dengan pernyataan Schulz tentang spirit of the place.

\section{Morfologi}

Morfologi lebih menekankan pada pembahasan bentuk geometrik, sehingga untuk memberi makna pada ungkapan ruangnya harus dikaitkan dengan nilai ruang tertentu. Dengan melihat kaitan ini, akan bisa dirasakan adanya kaitan yang erat antara organisasi ruang, hubungan ruang dan bentuk ruang, seperti:

1. Besaran dan ukuran yang luar biasa

2. Bentuk yang unik

3. Lokasi yang strategis
Namun demikian, juga dapat dicapai dengan cara lain yaitu nilai ruang yang menyangkut kualitas figural dalam konteks wujud pembentuk ruang yang dapat dibaca melalui pola, hierarki dan hubungan-hubungan satu dengan lainnya. Hal ini menunjuk pada cara mengidentifikasi karakteristik lingkungan yang diwujudkan melalui bentuk bangunan. Menurut Ching, (2015), sistem tata nilai keruangan bisa tercipta dengan adanya tiga hal, yaitu:

1. Perbedaan plat lantai yang bertingkat-tingkat

2. Tingkat kebersihan terhadap dekorasi ruang

3. Pewarnaan yang terang

Hampir semua bangunan memasukkan unsur-unsur yang sifatnya berulang, kolom dan balok berulang mengikuti modul tertentu. Seperti yang diungkapkan oleh Ching (2015) bahwa ada kecenderungan mengelompokkan unsur-unsur di dalam suatu posisi random, yang berdasarkan pada:

1. Kekompakan perletakan

2. Karakteristik visual yang dimiliki

Prinsip pengulangan memanfaatkan keduanya dari konsepsi untuk mengatur sesuatu yang berulang di dalam suatu komposisi. Contoh bentuk yang paling sederhana adalah pengulangan suatu pola linier dari berbagai unsur-unsur yang ada. Jika dikaitkan dengan kajian di atas mengenai Arsitektur Tradisional Minangkabau, dapat dikatakan bahwa:

1. Aspek topologi, yaitu orientasi kegiatan manusia pada tempat tertentu berdasarkan tatanan spasial dan organisasi ruangnya.

2. Aspek morfologi, yaitu identifikasi karakter lingkungan yang diwujudkan melalui bentuk bangunan, dimana kualitas figuralnya dapat dibaca melalui 
pola, hierarki dan hubungan antar ruang yang satu dengan lainnya.

\section{Metode Penelitian}

Metode yang dipakai dalam penelitian ini adalah metode riset empiris dengan analisis kualitatif yang bersifat deskriptif. Metode ini dipilih karena penelitian ini bergantung pada data dan informasi obyek studi yang terkumpul. Pendekatan kualitatif dilakukan karena penelitian ini akan membahas mengenai "kualitas" (makna) budaya pada elemen aristektur rumah Gadang Bodi Caniago di Sumatera Barat.

Pembahasan dalam tulisan ini dibagi menjadi tiga bagian, yaitu:

1. Bagian pertama, meliputi studi lapangan mengenai dua elemen aristektur rumah Gadang Bodi Caniago melalui interview dengan para tetua adat.

2. Bagian kedua, meliputi studi literatur mengenai makna budaya elemen aristektur rumah Gadang Bodi Caniago di Sumatera Barat dari buku teori Barat yang berfungsi sebagai teori pembanding.

3. Bagian ketiga, meliputi hasil pembahasan, kesimpulan dan konsep pengembangan dari elemen aristektur rumah Gadang Bodi Caniago di Sumatera Barat.

\section{Pembahasan}

Pada lareh Bodi Caniago, lantai balai adat dan rumah Gadang berlantai datar. Semua penghulu duduk sehamparan: duduk sama rendah, berdiri sama tinggi. Secara substansial, kedua sistem adat ini sesungguhnya samasama bertitik tolak pada asas demokrasi. Perbedaannya hanya terletak pada aksentuasi dalam penyelenggaraan dan prioritas pada hak asasi pribadi disatu pihak dan kepentingan umum dipihak lainnya. Ini merupakan fenomena yang sudah sama tuanya dengan sejarah kebudayaan umat manusia sendiri.

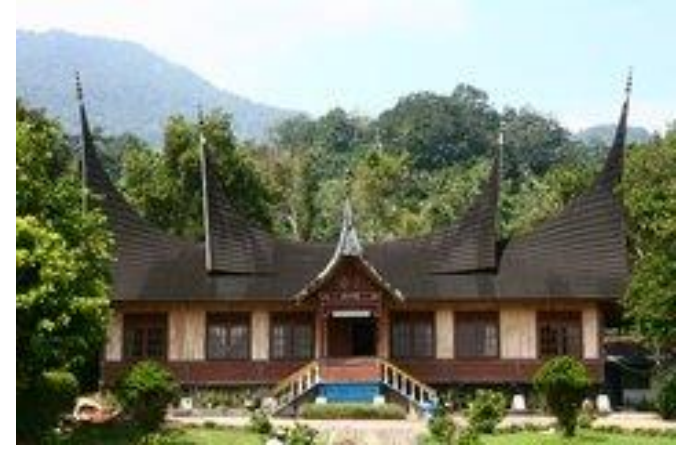

Gambar 1. Rumah Minangkabau Bodi Caniago sekarang Sumber:

http://baralekdi.blogspot.com/2011/01/ragamrumah-gadang-minangkabau.html

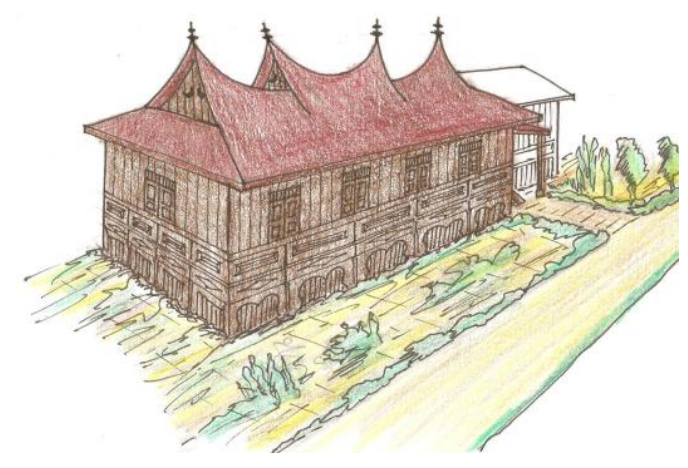

Gambar 2. Rumah Minangkabau Bodi Caniago Surambi Papek (Ragam Luhak Agam) Sumber:

http://baralekdi.blogspot.com/2011/01/ragamrumah-gadang-minangkabau.html

Semua penghulu duduk sehamparan duduk sama rendah, berdiri sama tinggi ini merupakan sebuah teori klasik yang mendasari terbentuknya bangunan seperti gambar 1, yaitu kebutuhan untuk melakukan upacara adat adalah pada area atau bagian depan bilik bangunan yang disebut dengan lanjar balai, labuah, bandua.

Dari penelitian sebelumnya, terungkap bahwa pada awalnya musyawarah itu 
dilakukan di luar bangunan. Susunan orang bermusyawarah mirip seperti susunan batu. Bentuk dan susunan orang bermusyawarah yang terdapat di di rumah Gadang Nagari Pariangan atau beberapa Nagari di Minangkabau memperlihatkan kemiripan dengan susunan batu, seperti diperlihatkan pada gambar berikut:
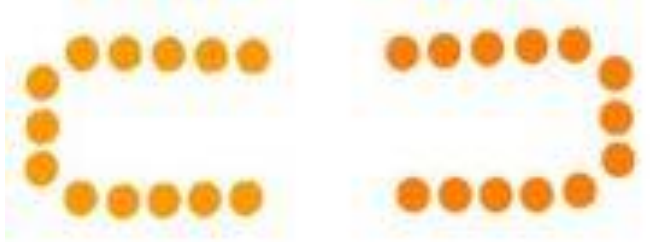

Gambar 3. Susunan batu tempat duduk untuk musyawarah adat Sumber:

http://visualheritageblog.blogspot.com/2010_0 7_25_archive.html

Susunan batu ini dapat kita bandingkan dengan susunan orang bermusyawah pada upacara adat di rumah Gadang, yang lazimnya seperti berikut ini:

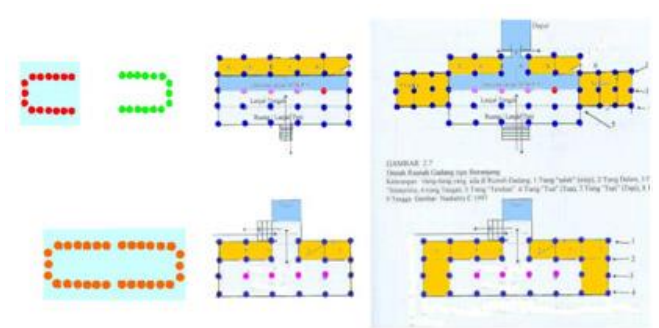

Gambar 4. Susunan tempat duduk untuk musyawarah adat dalam rumah Gadang Sumber:

http://visualheritageblog.blogspot.com/2010_0 7_25_archive.html

Masyarakat Minangkabau paling awal mengenal lambang empat (siampek) yang menurut A.A. Navis (1984) dan Nasbahry Couto (1998), lambang empat itu direpresentasikan dalam bentuk verbal dan visual. Dalam verbal misalnya seperti berikut ini:

1. Kato nan ampek (kato malereng, mandaki, manurun, mandata)

2. Keponakan nan ampek macam
3. Urang sumando nan ampek macam

4. Bilik/ kamar ada empat

5. Urang nan ampek jinih

6. Gonjong nan ampek, dst.

Jadi, ketentuan gonjong harus berjumlah empat buah diikuti oleh nagari yang patuh terhadap aturan adat ini, sedangkan nagari lain yang menganggap hal ini tidak penting, tidak mengikuti ketentuan ini. Misalnya, rumah adat di Muarolabuah ada yang gonjongnya berjumlah delapan, enam, dsb.

Untuk menggambarkan serba empat itu dalam bangunan, maka lanjar dibuat empat (bilik, bandua, labuah, balai) seperti yang terlihat pada gambar 4 . Salah satu kesulitan dalam membangun empat ruang (bilik) adalah karena adanya pantang - larang sebuah bilik tidur tidak boleh bertentangan dengan pintu masuk (kepercayaan animisme dan magisme). Sebagai jalan keluarnya, maka dibangun 5 buah: satu yang ditengah dianggap tabu untuk dipakai karena bertentangan dengan pintu masuk. Biasanya bilik kosong ini dipakai sebagai tempat penyimpanan barang (gudang).

Angka genap adalah angka yang dipakai ditambah dengan satu ruang, maka bilangan bilik selalu dalam angka 3, 5, 7 dan 9 yang dipakai dalam membangun rumah adat atau rumah Gadang. Dari penelitian di lapangan ternyata etnik Minang masa lampau menghubungkan simbolisasi rumah Gadang dengan unsur animistik, kepercayaan Hindu dan berbaur dengan unsur magis. Demikian juga dalam hal angka-angka ganjil seperti angka 3, 5, 7, 9 yang dipakai dalam tata atur bangunan.

Lambang empat itu digambarkan pada jumlah gonjong, walaupun jumlah 
bilik bangunan $3,5,7,9$ dan seterusnya, gonjong tetap dibuat empat buah. Lambang ini juga diterapkan pada pembagian komunitas, misalnya:

1. Taratak, Dusun, Koto, Nagari

2. Pada pembagian lanjar: bilik, bandua, labuah, balai

3. Pada pembagian suku: Koto, Piliang, Bodi Caniago

4. Pada simbol tiang rumah Gadang, dsb.

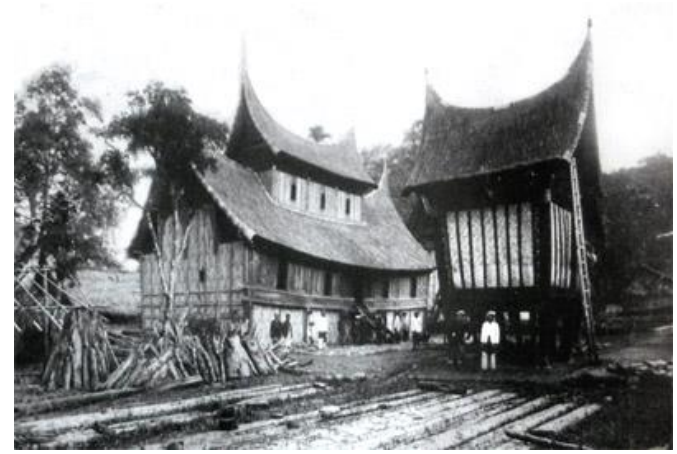

Gambar 5. Penempatan dan model ukiran mirip dengan bangunan asli yang ada di

Pariangan. Tangga tanpa atap dan lima ruang, ditandai dengan empat buah jendela, ditambah dengan satu pintu masuk di tengah bangunan

Sumber:

http://visualheritageblog.blogspot.com/2010_0 7 25_archive.html

Secara simbolik, lengkungan atap pada rumah Gadang di Sumatra Barat kerap diyakini mirip bentuk tanduk kerbau atau rebung (bambu muda). Selain itu, ada juga yang merujuknya pada bentuk layar kapal. Jika tanduk kerbau dan rebung berkaitan dengan budaya pertanian, bentuk kapal mencerminkan budaya merantau.

Rumah adat ini memiliki keunikan bentuk arsitektur dengan bentuk puncak atapnya runcing, menyerupai tanduk kerbau yang dahulunya dibuat dari bahan ijuk yang dapat tahan sampai puluhan tahun, namun belakangan atap rumah ini banyak diganti dengan atap seng.

\section{Fungsi Rumah Gadang} Minangkabau Lareh Bodi Caniago

Selain sebagai tempat kediaman keluarga, fungsi rumah Gadang juga sebagai lambang kehadiran suatu kaum, sebagai pusat kehidupan dan kerukunan, seperti tempat bermufakat dan melaksanakan berbagai upacara, bahkan juga sebagai tempat merawat anggota keluarga yang sakit.

Sebagai tempat tinggal bersama, rumah Gadang mempunyai ketentuanketentuan tersendiri. Setiap perempuan yang telah bersuami memperoleh sebuah kamar. Perempuan yang termuda memperoleh kamar yang terujung. Pada gilirannya, ia akan berpindah ke tengah jika seorang gadis memperoleh suami pula. Perempuan tua dan anak-anak memperoleh tempat di kamar yang dekat dengan dapur. Sedangkan gadis remaja memperoleh kamar bersama pada ujung yang lain.

Sedangkan laki-laki tua, duda dan bujangan tidur di surau milik kaumnya masing-masing. Penempatan pasangan suami istri baru di kamar yang terujung ialah agar suasana mereka tidak terganggu oleh kesibukan dalam rumah. Demikian pula menempatkan perempuan tua dan anak-anak pada suatu kamar yang dekat dengan dapur ialah karena keadaan fisiknya dan memerlukan untuk turun naik rumah pada malam hari.

Sebagai tempat bermufakat, rumah Gadang merupakan bangunan pusat dari seluruh anggota kaum dalam membicarakan masalah mereka bersama. Sebagai tempat melaksanakan upacara, rumah Gadang menjadi penting untuk meletakkan tingkat martabat mereka pada tempat 
yang semestinya. Di sana juga dilakukan penobatan penghulu. Di sana merupakan tempat pusat perjamuan penting untuk berbagai keperluan dalam menghadapi orang lain dan tempat penghulu menanti tamu-tamu yang mereka hormati.

Pada umumnya rumah Gadang didiami nenek, ibu dan anak-anak perempuan. Bila rumah itu terlalu sempit, rumah lain akan dibangun di sebelahnya. Seandainya rumah yang akan dibangun itu bukan rumah Gadang, maka lokasinya berada di tempat lain yang tidak sederetan dengan rumah Gadang tersebut.

\section{Elemen Rumah Gadang}

\section{Minangkabau Lareh Bodi Caniago}

1. Sandi

Setiap kaki tonggak berdiri di atas sebuah batu disebut dengan sandi. Sandi batu didatangkan kemudian setelah semua tiang dihubungkan oleh rasuk dan paran-paran. Paran ialah sebuah kayu atau ruyung panjang dari pohon kelapa yang menghubungkan setiap tiang pada ujung atas. Sama dengan rasuk, ada yang disebut paran panjang dan paran melintang. Punco-punco tiang yang dihubungkan oleh paran panjang tidak sama pula tingginya hingga terlihat lengkungnya atau disebut paran ular mangulai (mengulai). Lengkung paran inilah yang akan membentuk gonjong (pucuk atap).

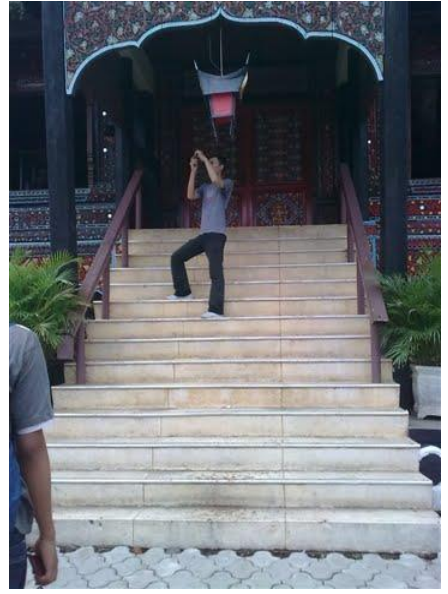

Gambar 6. Sandi rumah Minangkabau Bodi Caniago Surambi Papek (Ragam Luhak Agam)

Sumber:

http://baralekdi.blogspot.com/2011/01/ragamrumah-gadang-minangkabau.html

2. Tangga

Tangga pada sebuah rumah Gadang terbuat dari material kayu dan biasanya diawali dengan sebuah batu alam datar, jumlah anak tangga pada rumah Gadang berjumlah ganjil misalnya 5,7 dan 9 .

3. Tiang

Tiang rumah Gadang berbentuk dasar bulat yang dibuat bersegi-segi. Tidak ada tiang rumah Gadang yang terbuat dari kayu bulat. Tiang merupakan bagian penting dari bangunan. Segi-segi dari tiang tidak sama besarnya. Tiang yang besar terdapat pada tengah bangunan dan tiang yang berada di tengah bangunan dibuat bersegi 8 , sedangkan yang terletak di samping bersegi 5 . 


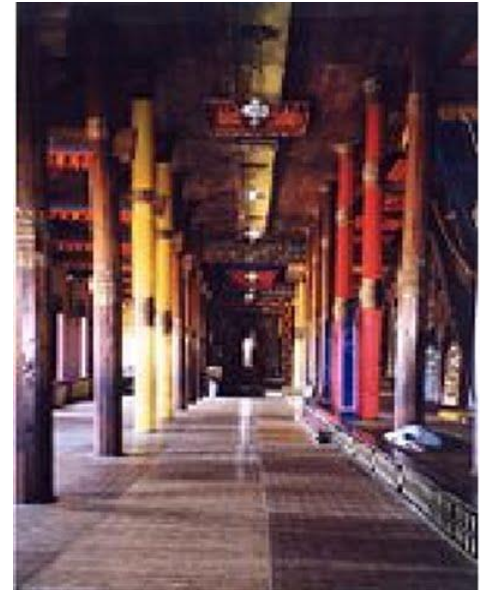

Gambar 7. Tiang rumah Minangkabau Bodi Caniago Surambi Papek (Ragam Luhak Agam)

Sumber:

http://baralekdi.blogspot.com/2011/01/ragamrumah-gadang-minangkabau.html

\section{Dinding}

Dinding pada rumah Gadang terdiri atas 3 bagian, yaitu dinding depan, dinding sasak dan dinding samping.

Secara umum dinding pada rumah Gadang tersebut terbuat dari anyaman bambu yang diikat oleh papan - papan sebagai tulangannya. Semua dinding rumah Gadang terbuat dari papan, terkecuali dinding bagian belakang yang terbuat dari bambu.

Papan dinding dipasang vertikal. Pada pintu dan jendela serta pada setiap sambungan papan pada paran dan bendul terdapat papan bingkai yang lurus dan juga berelung. Semua papan yang menjadi dinding dan menjadi bingkai diberi ukiran, sehingga seluruh dinding penuh ukiran. Ada kalanya tiang yang tegak di tengah juga diberi sebaris ukiran pada pinggangnya. Sesuai dengan ajaran falsafah Minangkabau yang bersumber dari alam terkembang, sifat ukiran adalah non-figuratif, tidak melukiskan lambang-lambang atau simbol-simbol.

Pada dasarnya, ukiran itu merupakan ragam hias pengisi bidang dalam bentuk garis melingkar atau persegi. Motifnya tumbuhan merambat yang disebut akar yang berdaun, berbunga dan berbuah. Pola akar itu berbentuk lingkaran. Akar berjajaran, berhimpitan, berjalinan dan juga sambung-menyambung. Cabang atau ranting akar itu berkeluk ke luar, ke dalam, ke atas dan ke bawah. Ada keluk yang searah di samping dan ada yang berlawanan. Seluruh bidang diisi dengan daun, bunga dan buah.

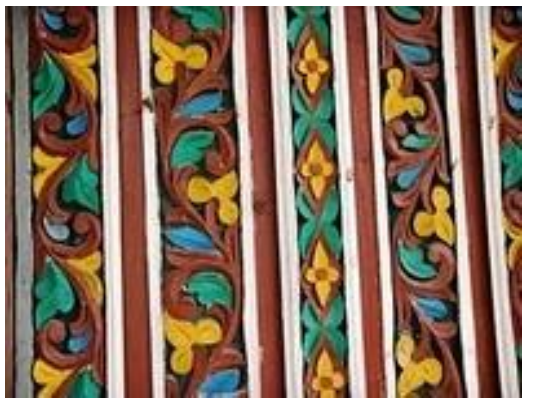

Gambar 8. Ukiran pada dinding rumah Minangkabau Bodi Caniago Surambi Papek (Ragam Luhak Agam) Sumber:

http://helena-hapsari.blogspot.com/2010/01/rumahgadang.html

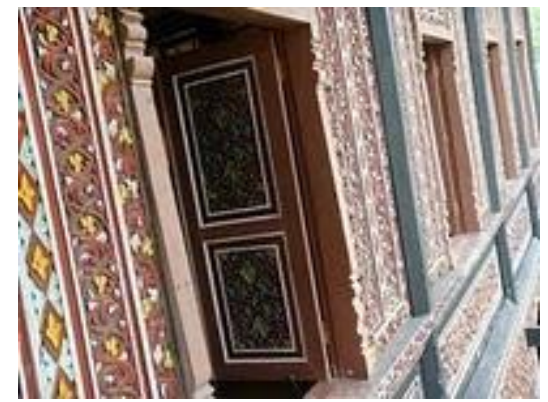

Gambar 9. Ukiran pada dinding rumah Minangkabau Bodi Caniago Surambi Papek (Ragam Luhak Agam) Sumber:

http://helena-hapsari.blogspot.com/2010/01/rumahgadang.html 
5. Lantai

Lantai rumah Gadang terbuat dari papan. Lantai papan dipasang di atas jeriau dan ada kalanya lantai dibuat dari pelupuh (bambu yang dipecah). Ungkapan adat untuk lantai rumah Gadang ini adalah "lantai banamo hamparan adat, tampek si janang main pantan, tampek penghulu main undang." Lantai rumah Gadang ada dua jenis bila dilihat dari bentuknya. Lantai datar untuk semua bidang merupakan jenis Bodi Caniago, dimana semua penghulu yang duduk sama martabatnya, dengan kata-kata adatnya duduak samo randah, tagak samo tinggi.

6. Atap

Rumah Gadang biasa disebut rumah Gonjong atau rumah Bagonjong karena atapnya berbentuk bergonjong runcing menjulang. Ini adalah nama yang membedakan dengan rumah biasa. Lengkungan pada atap tajam seperti garis tanduk kerbau, sedangkan lengkung pada badan rumah landai seperti badan.

Gonjong adalah bagian yang paling tinggi dari setiap ujung atap yang menghadap ke atas dan merupakan ujung turang yang dibalut dengan timah yang berbentuk:

- 2 labu-labu di bagian bawah

- 1 belimbing di atas labu-labu

- 1 anting-anting di atas belimbing

- 1 ujung yang tajam di atas anting-anting

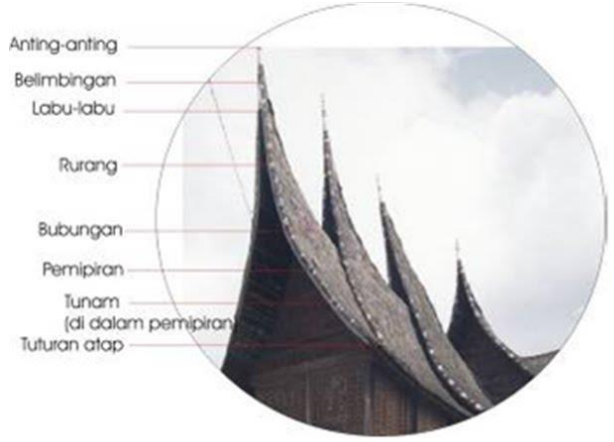

Gambar 10. Atap rumah Minangkabau Bodi Caniago Surambi Papek (Ragam Luhak Agam) Sumber:

http://helena-hapsari.blogspot.com/2010/01/rumahgadang.html

Antara labu-labu, belimbing dan anting-anting ada peraturan yang searah dengan ujung yang paling atas. Kombinasi bentuk gonjong yang seperti ujung tanduk kerbau jantan dinamakan 'isendak langit'. Turang adalah bagian di bawah gonjong sampai ke batas garis lurus bubungan atas kepemimpinan. Turang ini adalah tempat penahan gonjong. Kombinasi bentuk turang dengan gonjong itulah yang berbentuk 'rabuang mambacuik'. Keseluruhannya (antara turang dan gonjong) disebut gonjong saja.

Atap terbuat dari ijuk. Saga ijuk diatur susunannya dengan nama Labah Mangirok atau Labah Maraok dan Bada Mudiak. Bubungan seperti legkungan sayap burung burak akan terbang. Lengkungan bubungan terletak antara dua gonjong yang di tengah. Gonjongnya seperti rebung yang mula keluar dari tanah. Pucuk gonjong mencuat ke atas.

\section{Hasil dan Pembahasan}

\section{Aspek Topologi}

Masyarakat Minangkabau menganut sistem kekeluargaan matrilineal (garis keturunan ibu), dimana pihak ibu 
menjadi patokan dalam silsilah keturunan suatu keluarga. Dengan demian, tempat tinggal yang disediakan juga hanya untuk perempuan dan anak-anak, sementara laki-laki pergi ke surau untuk menuntut ilmu dan belajar mengaji, seperti yang dikatakan oleh Navis (1984).

Setiap keluarga atau suku mempunyai tempat tinggalnya masing-masing yang disebut dengan rumah Gadang. Rumah Gadang berfungsi sebagai tempat bersama suatu kaum, selain itu juga sebagai pusat aktivitas suatu kaum. Dalam rumah Gadang banyak kegiatan yang dilakukan, mulai dari hunian sampai tempat pengobatan dan juga tempat pertemuan-pertemuan adat ataupun perkawinan. Oleh karena banyaknya aktivitas yang dilakukan di rumah Gadang, akhirnya rumah Gadang itu dikatakan gadang (besar), jika diartikan secara simbolis.

Lahan yang dipergunakan untuk membangun rumah Gadang ini memakai lahan suatu kaum. Hal ini disebabkan karena rumah Gadang ini diperuntukkan untuk kegiatan kelompok atau kaum atau keluarga tersebut. Kepemilikan bangunan menjadi hak milik kaum tersebut sampai generasi yang akan datang, dimana setiap generasi saling bergantian memakainya. Hal di atas menggambarkan eratnya kebersamaan suatu kaum atau keluarga dalam beraktivitas, sampai-sampai untuk tempat tinggal pun selalu bersamasama.

Seperti yang diungkapkan oleh Schutz dalam Agus (1999) tergambar bahwa rumah Gadang menjadi pusat dan orientasi aktivitas suatu kaum, mulai dari hunian sampai ke pertemuan dan pengobatan. Sehingga, tempat-tempat lainnya hanya bersifat penunjang dan pelengkap. Rumah Gadang menjadi pusat orientasi disebabkan adanya kerukunan dan kekeluargaan yang tinggi dalam suatu kaum, sehingga menjadi tempat-tempat untuk beraktivitas sosial semata dalam suatu nagari, baik untuk beribadah, bergaul dan bekerja.

Rumah Gadang mempunyai bentuk dan pola denah dari bentuk persegi panjang, hal ini bertujuan untuk dapat menampung semua aktivitas dan luasan yang lebih besar untuk ruang gerak. Seluruh ruang dalam rumah Gadang merupakan ruang lepas, terkecuali kamar tidur yang disekat dengan dinding pembatas. Bagian dalam rumah Gadang terbagi atas lanjar dan ruang, ditandai dengan tiang sebagai pembatas. Sedangkan material yang dipakai dalam rumah Gadang ialah material alam.

Ruang tengah menjadi pusat orientasi kegiatan yang bersifat indoor, dimana di ruang ini menjadi tempat menjamu tamu, rapat kaum dan juga tempat makan. Dari ruang tengah alur gerak diarahkan ke bilik-bilik (kamar tidur) dan juga ke dapur di bagian belakang. Setiap lanjar atau ruang mempunyai fungsi tetentu yang diatur dalam tambo dan juga adat istiadat yang berlaku. Hal ini mencerminkan adanya norma yang mengatur demi ketertiban bersama.

\section{Aspek Morpologi}

Falsafah yang dianut masyarakat Minangkabau adalah alam takambang jadi guru, dimana alam diciptakan dengan sempurna dan di dalamnya terdapat banyak contoh pengajaran yang baik. Masyarakat Minangkabau juga demikian, mencoba hidup selaras dengan alam lingkungannya, dinamis dan terdapat hubungan timbal balik sebagaimana disebut "bakarang 
bakarangko" (sebab akibat) sehingga setiap buah karya yang dihasilkannya selalu mencoba mengambil dari alam dan menyelaraskannya dengan lingkungan yang ada, baik itu buatan maupun alami.

Demikian juga dengan arsitektur Minangkabau, bentuk yang dikenal luas adalah rumah bagonjong, dimana atapnya melengkung dan badan rumah yang melendut dibagian tengahnya. Rata-rata bentuk arsitektur Minangkabau memang mempunyai bentuk yang demikian, baik itu untuk rumah Gadangnya, balai adat, tabuah, rangkiang, balai ruang dan lain-lain. Ada beberapa pendapat yang berkaitan dengan bentuk atap gonjong ini, yaitu ada yang mengatakan berasal dari tanduk kerbau, daun sirih, layar kapal dan bentuk rebung muda. Disamping itu, bentuk gonjong yang meruncing ke atas bekesan berlawanan dengan bentuk bukit barisan alam Minangkabau, tetapi dari segi estetika mempunyai bentuk yang menarik dan harmonis.

\section{Kesimpulan}

Arsitektur Rumah Gadang Bodi Caniago di Sumatra Barat benar-benar merupakan ungkapan dan cerminan sosial budaya masyarakatnya yang mempunyai landasan yang kuat dan khas, baik strukturnya, bentuk, tata ruang dan juga pemakaian ornamenornamennya dan bentuk yang selaras dengan lingkungannya, keserasian antara alam dan lingkungan binaan yang diciptakan. Sehingga bentuk yang mempunyai dasar yang kuat dan ciri khas tersebut mudah diingat dan dikenal orang atau pengamat. Elemenelemen yang ditampilkan secara utuh dan menyatu memberikan inspirasi pengembangan budaya bagi masyarakat Minangkabau.
Pelestarian rumah tradisional rumah Gadang Bodi Caniago di Sumatra Barat hendaknya dilakukan secara ideal sehingga mampu menguatkan nilai budaya arsitektur Minangkabau.

\section{Daftar Pustaka}

Agus, Elfida. (1999). Tipologi dan morfologi arsitektur (Diktat kuliah, Jurusan Arsitektur Fakultas Teknik Sipil dan Perencanaan Universitas Bung Hatta, $1999 . \quad$ Tidak dipublikasikan).

Ching, F.D.K. (2015). Architecture: form, space and order. New York: Van Nostrand Reinhold Company.

Couto, Nasbahry. (1998). Makna dan unsur-unsur visual pada bangunan rumah Gadang (Tesis Pasca Sarjana Jurusan Seni Murni Fakultas Seni Rupa dan Desain ITB, 1998. Tidak dipublikasikan).

Navis, A.A. (1984). Alam takambang jadi guru. Jakarta: Grafiti Pers.

Usman, Ibenzani. (1995). Perkembangan arsitektur III (Diktat kuliah, Jurusan Arsitektur Fakultas Teknik Sipil dan Perencanaan Universitas Bung Hatta,1995. Tidak dipublikasikan). 